\title{
Uracil Mustard
}

National Cancer Institute

\section{Source}

National Cancer Institute. Uracil Mustard. NCI Thesaurus. Code C918.

An alkylating derivative of the pyrimidine nucleobase uracil that is bound to nitrogen

mustard, with antineoplastic activity. Uramustine alkylates and damages DNA by binding to the guanine and cytosine moieties of DNA. This leads to cross-linking of DNA, which inhibits DNA synthesis and promotes cell death in rapidly metabolizing cells, such as cancer cells. 